\title{
Ore Mineralization of Active Paleomargins of Continents (on the Example of Alpine Metallic Deposits of Caucasus and Pontides)
}

\author{
Sergo Kekelia*, Nona Gagnidze, Ira Mshvenieradze, Giorgi Kharazishvili \\ Department of Geochemistry and Mineral Resources, Al. Janelidze Institute of Geology, Tbilisi State University, Tbilisi, Georgia \\ Email address: \\ sergokekelia@yahoo.com (S. Kekelia), nonagagnidze@gmail.com (N. Gagnidze), iramshvenieradze@gmail.com (I. Mshvenieradze), \\ gkharazishvili@tsu.ge (G. Kharazishvili) \\ ${ }^{*}$ Corresponding author
}

\section{To cite this article:}

Sergo Kekelia, Nona Gagnidze, Ira Mshvenieradze, Giorgi Kharazishvili. Ore Mineralization of Active Paleomargins of Continents (on the Example of Alpine Metallic Deposits of Caucasus and Pontides). Journal of Energy and Natural Resources. Vol. 10, No. 1, 2021, pp. 1-13. doi: $10.11648 /$ j.jenr.20211001.11

Received: December 2, 2020; Accepted: February 2, 2021; Published: February 23, 2021

\begin{abstract}
Metallogenic features of Pontides - Lesser Caucasus microplates (part of active paleomargin of Eurasian microplate are determined by copper, copper-molibdenium porphyry, iron-scarn, volcanic nonferrous, precious metals, auriferous and manganese ore deposits. Their orebearing fluid systems occurred consistently on various stages of development of the region and were correlated with geological processes on the border of convergental and divergental interaction of microplates. The above mentioned types of ore deposits display clear areal and temporary bonds with certain composites of lithogeodynamic complexes (which are presented in mountain folding systems of relics of ancient geomorphological structures) - geological formations. Different geologic-genetical models are suggested for each type of deposits, characterizing possible sources of ore substance, causes of rise and functions of fluid systems, in addition to ore formation environment. It may be said that different genetic groups of deposits are regularly associated with certain litho-geodynamic complexes. The complexes of the paleomarginal sea hollows of the divergent type are specialized in copper and pyrite-polimetallic hydrothermalsedimentary mineralization; island arc systems of different age - in copper and copper-zinc hydrothermal-sedimentary and epigenetic mineralization; their uplifted blocks - in gold, copper-porphyry and skarn-iron-ore mineralization. Within the area of volcanic-sedimentary copper-zinc deposits in intra-arc sea hollows (Pontides) manganese accumulations are sometimes encountered.
\end{abstract}

Keywords: Metallogeny, Deposit, Mineralization, Caucasus, Pontides

\section{Introduction}

Metallogenic peculiarities of active paleomargins of continents are discussed on the example of the central segment of the Mediterranean-Himalayan mountain-fold belt; in particular, the complex interaction between a fragment of the Eurasian continent - the Pontian-Transcaucasian microplate and the Gondwanian continental blocks Kirshakhir, Taurus and Daralagez (Figure 1).

Within the central part of the Mediterranean-Himalayan mountain-fold belt there are fragments of ancient continentalmargin structures - paleoisland arc, backarc and intra-arc paleobasins. Here within these structures economic vol- canogenic deposits of non-ferrous metals concentrated. Among the most important geological events that conditioned the tectonic setting [1] of this mountain-fold belt segment are: (1) the partition of the South Armenian-Iranian microplate from the north margin of Gondwana in PermianTriassic time and its accretion to the active Passific-type continental margin of the Eurasian continent [2]; (2) the opening of a rift in Late Triassic-Early Jurassic that was later transformed into a branch of the Neotethys [3]; (3) the obduction of oceanic complexes in Senonian that heralded the "death" of the Tethys ocean [2]. The further development 
of the region during the late Alpine cycle was conditioned by the interaction of the Scythian and South Caucasian-Pontian microplates (active paleomargin of the Eurasian continent) with the northernmost lithosperic blocks of Gondwana (Kirshakhir, East Taurus, Daralagez etc.). At present, the boundaries between these mobile blocks of the earth's crust (sometimes referred to as terrains) are represented by large fault zones commonly with evidence of significant dip-slip and strike-slip displacements and are marked by basitic and ultrabasitic ophiolitic complexes and tectonic mélange (Figure 1).

It should be noted that the above-mentioned geologic events of the Alpine cycle were accompanied by the following processes: (1) the divergency of microplates (crustal blocks) in Triassic-Early Bajocian and the activation of the processes of mantle diapirism; (2) the convergence of the microplates in late Bajocian-earliest late Cretaceous accompanied by specific island-arc volcanism revealed in both uplifted blocks (subaerial environments) and restricted deep basins that existed within the South Caucasian-Pontian province. The maximum activity of this islandarc volcanism occurred in the South Caucasus in Bajocian-late Jurassic and in the Pontides - in Turonian-Santonian. According to the reference [4] in the geodynamic evolution of the western and eastern parts of the islandarc system there are obvious distinctions. It was also shown that the start of the collision, between South Caucasian and Daralagez blocks, happened in Coniacian whereas that between Pontides and Anatolides - in Campanian [2, 5].

During the convergent stage, within the active continental margin of the Eurasian plate appeared thermoanomalies whose location was generally controlled by tectonic factors; these anomalies commonly coincide spatially with areas experienced maximum tectonic deformations and are characterized by increased fracturing and faulting. These areas reveal enhanced magmatic and volcanic activity and wide development of hydrothermal processes. The submarine environments that dominated in the region during the early Alpine cycle (middle Jurassic - late Cretaceous) were conducive to the formation and preservation of volcanichosted mineral deposits.

At first, in the Jurassic time, epigenetic volcanogenic copper and barite-polymetallic deposits were formed (Alaverdi, Shamlug, Kafan, Akhtala) which were followed in the early Cretaceous by the Tekhut-type porphyry copper deposits. All the above deposits are located within the Armenian part of the Lesser Caucasus. In the activated deep restricted volcano-depressions epigenetic copper, goldbearing and barite-polymetallic deposits of the Bolnisi-type (Georgia) were formed. To the west, in the Eastern Pontides, in late Cretaceous developed (intra-arc basins) volcanic- and sediment-hosted copper-zinc ores of the Çayeli-type as well as the large-scale epigenetic mineralization (Murgul and some others).

The deposits reveal distinct relationships with the specific lithogeodynamic complexes of paleoisland arc constructions. Some of them (some deposits in Turkey) create integral spatial-temporal associations with enclosing volcanites; the others were formed somewhat later than the enclosing rocks, but the time of their formation remained within the limits of formation of volcanic-host complexes.

Within the Pontian-Transcaucasian microplate, the postcollisional stage (Oligocene-Quarternary) coincides in time with accelerated northward propagation of the Arabian wedge and the subduction of the African plate. This time in the region was characterized by activization of transversal fault zones and formation of the Paratethys (Black SeaCaspian basin) followed by an active growth of the mountain-fold construction. In the metallogenic sense, the most productive was the initial phase of the stage with the generation of manganese accumulations in the marginal parts of the Paratethys, whereas within the Kirshakhir and Taurus blocks, and at the junction of the Transcaucasian and Daralagez blocks arose gold-bearing, copper-molybdenumporphyry and rare-metal deposits related to the formation of intrusive complexes.

It may be said that different genetic groups of deposits are regularly associated with certain litho-geodynamic complexes. The complexes of the paleomarginal sea hollows of the divergent type are specialized in copper and pyritepolymetallic hydrothermal-sedimentary mineralization; island arc systems of different age - in copper and copper-zinc hydrothermal-sedimentary and epigenetic mineralization; their uplifted blocks - in gold, copper-porphyry and skarn-iron-ore mineralization. Within the area of volcanic-sedimentary copper-zinc deposits in intra-arc sea hollows (Pontides) manganese accumulations are sometimes encountered.

Paleozoic and Early Mesozoic flyschoid sequences activized in Bathonian and Cenozoic reveal gold mineralization. Complexes of shelf zones composed of carbonate sediments generally contain barite and lead-zinc mineralization. The collisional (Eocene) volcanostructures are characterized by small-scale epigenetic pyritic, polymetallic (with gold and silver), copper-porphyry and skarn-iron-ore occurrences. The suture zones are saturated with mercury, arsenic, stibnite and gold occurrences. The blocks of mountain-fold constructions that experienced late collisional-post collisional tectono-magmatic activization enclose large copper-molybdenum-porphyry (Kadzharan and Agarak in Armenia) deposits. Outside the PontianTranscaucasian microplate, the product of the activization of this time is the skarn molybdenum-tungsten and rare metal mineralization.

\section{Example of Deposits and Conditions of Their Formation}

Figure 1 shows that the metallogenic potential of the Pontian-Transcaucasian microplate is defined by: plutogenic copper- and copper-molybdenum-porphyry; volcanogenic copper and polymetallic; gold-bearing in volcano-plutonic belts, suture zones and carboniferous sequences; skarn-ironore and manganese deposits. 


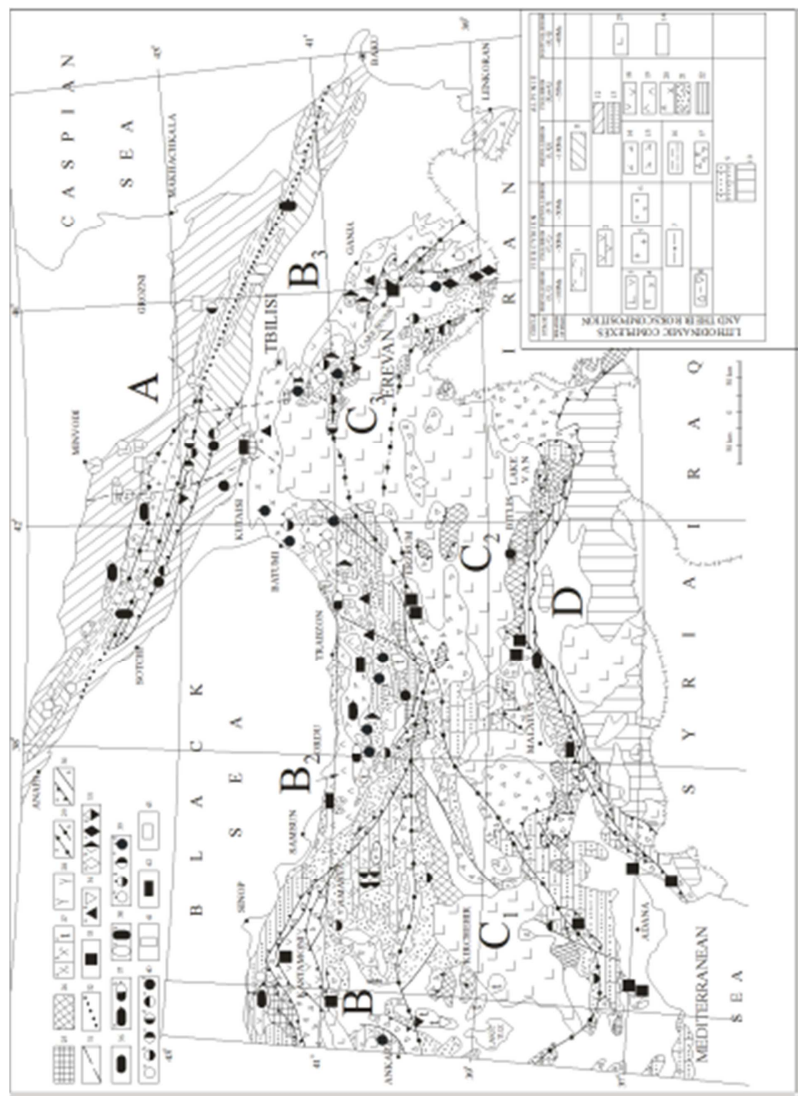

Figure 1. Scheme of distribution of litho-geodynamic complexes and main types of metallic deposits of the central part of the Alpine-Hymalayan belt (Eastern Turkey and the Caucasus).

Litho-geodynamic complexes: Hercynian:active margin of the East European paleocontinent: 1 - shelf and continental slope (ndesite-basalts, coaly-clay shales, Greater Caucasus); 2 - shelf zones of the continent (Carboniferous-Triassic sandstones, conglomerates, coaly shalesPontides); 3 - ensimatic island arc rhyolites; Greater Caucasus); 4- ensialic island arc Caucasus); 6 - continental depressions (clays, (basalts, sandstones, andesite-basalts; Greater Caucasu(gabbro, granodiorites, parametamorphites of greenschist and amphibolite facies, blocks of pre-Cambrian schists; Greater Caucasus); 5 - uplifted activized blocks of ensialic arc 7 - paleomarginal sea (coaly-clayey shales, sandstones; Southern Slope of the Greater Caucasus); 8 - oceanic bed (calcareous and flint shales, basalts, peridotites; Greater Caucasus). Passive margin of Gondwanaland and later, since Mesozoic, of Afro-Arabian paleocontinent: 9 - shelf zones (clays; Kirsehir, Taurus, Daralagez blocks); 10 - shelf zone of Arabian projection (sandstones, clays, limestones). Alpine: active margins of the Eurasian paleocontinent: 11 -continental slope and rise of the Transcaucasian microcontinent (andesite-basalts, trachyandesites, terrigenous-calcareous flysch; southern slope of Greater Caucasus); 12 - shelf zones and slopes of the Scythian and Transcaucasian microcontinents (andesites, andesite-basalts; Greater Caucasus); 13 - shelf zones and slope of the Pontian microcontinent (andesite-basalts, sandstones; Pontides); 14 - Lesser Caucasian ensimatic island arc (andesite-basalts, rhyodacites, tuffites; southern margin of the Transcaucasian microcontinent); 15 - Pontian ensimatic island arc (andesite-basalts, rhyodacites, marls, sandstones); 16 - troughs within the marginal paleo-sea (shales, basalts; Greater Caucasus); 17 - oceanic zones in allochthonous occurrence (in the form of sutural and obducted deformed slabs - ultrabasic "melange", harzburgites, serpentinites; Pontides, Taurides, Lesser Caucasus); 18 - residual Lesser Caucasian back-arc paleodepressions, (andesites, rhyodacitic ignimbrites); 19 - residual Pontian back-arc paleodepressions (basalts, rhyodacites, trachyr odepressions (andesites, trachyandesites); 20 - intraplate superimposed riftogenic depressions (trachyandesites, trachybasalts, volcano-terrigenous flysc; 21 - superimposed marine volcanmarls, shales; 22 - troughs (south margin of the Taurus) emerging as a result of collision of the Taurus hwith Eurasia (sandstones, hyolites);); 23 - volcanic plateau-activated blocks of fold systems (, andesite-basalts, basalts and their pyroclastics); 24 - intramontane depressions and foredeeps of fold systems (Oligocene-Quaternary marine and continental Neogene-Quaternary andesites molasse); 25 - crystalline basement of the Eurasian continent (pre-Cambrian-Early Paleozoic); 26 - crystalline basement of Afro-Arabian continent (pre-Cambrian?); 27 granitoids (pre-collisional: a - Lower Cretaceous, b - Upper Cretaceous, c - Eocene-Oligocene collisional); 28 - post-collisional monzonites, syenites, granodiorites; 29 - suture zones); 30 - faults ( $\mathrm{a}$ - thrusts and reverse faults, $\mathrm{b}$-subvertical faults); 31 - Caucasian lineaments interpreted from space photographs; 32 - presumable boundary between Scythian and Transcaucasian microplates. Genetic types of deposits: 33-magmatogenic (chrome minerals); 34 - skarn ( $a$ - iron-ore, $b$ - tungstenmolybdenum); 35 - hydrothermal-plutogenic (a - polymetallic, b - copper-porphyry, c -copper-molybdenum-porphyry, d - gold-bearing); 36 - hydrothermalsedimentary in volcanic rocks (cop-per with zinc); 37 - combined hydrothermal-sedimentary and stockwork in volcanic rocks (a - copper, $\mathrm{b}$ - copper-zinc); 38 hydrothermal-sedimentary in shales ( $\mathrm{a}$ - polymetallic, $\mathrm{b}$ - copper metamorphogenic); 39 - hydrothermal-volcanogenic epigenetic ( $\mathrm{a}$ - copper, $\mathrm{b}$ - polymetallic with barite, c - polyformational: copper, barite, barite-polymetallic, gold-bearing in secondary quartzites, $\mathrm{d}$ - gold-bearing); 40 - hydrothermal "amagmatogenic"telethermal ( $\mathrm{a}$ - mercury, $\mathrm{b}$ - arsenic-realgar-orpiment with gold, $\mathrm{c}$ - arsenic-orpiment with gold, $\mathrm{d}$ - gold-antimony, e - lead-zinc in calcareos rocks, $\mathrm{f}$ - barite); 41 hydrothermal-metamorphogenic (tungsten); 42 - sedimentary and volcanogenic-sedimentary (?) (manganese); 43 - sedimentary (celestine). The paleomargin of the Eurasian continent active during the Alpine cycle: microplates: A - Scythian, B - Pontian-Transcaucasian ( $\mathrm{B}_{1}$ - Western Pontides, $\mathrm{B}_{2}$ - Eastern Pontides, $\mathrm{B}_{3}$ Transcaucasia).

Passive paleomargins of the Afro-Arabian continent: microplates: $C_{1}-$ Kirshehir, $C_{2}$ - Taurus, $C_{3}$ - Daralagez (North Iranian). Microplates are divided by suture zones. D - Arabian projection

The western part of the scheme is compilied on the base of maps published by MTA (Turkey): geological, on a scale 1:500 000 (1961) and 1:2 000 000 (1989); metallogenic, on a scale 1:2 500000 (1977) and 1:1 000000 (2000). Besides, it has been used an unpublished map of the Eastern Pontides on a scale 1:250 000. 


\subsection{Porphyry Deposits}

The deposits are known in the Lesser Caucasus and the Pontides. Within the latter, they are encountered in both the Cretaceous and the Tertiary intrusive formations. Relatively large (154.7 m.t. of ore) in the Pontides is the Guzelyala deposit situated $40 \mathrm{~km}$ south of the city of Trabzon in the granite -porphyry rocks intruding the Early Jurassic and Late Cretaceous volcanites [6]. Here, a common succession of metasomatites has been identified: the inner zones are composed of quartz- K-feldspar metasomatites, replaced by argillites and, later, by prophylites. A typical example of the pre-collisional copper-porphyry deposits is Tekhut, whereas the largest post-collisional copper-molybdenum-porphyry deposit is Kadzharan in the Lesser Caucasus.

In the Tekhut deposit, the copper-bearing tonalite-porphyry paleosystem occupies the apical parts of a large (out cropping are about 90 sq. $\mathrm{km}$ ) phaneritic quartz-diorite-tonalite intrusion of the Cretaceous age. The steeply dipping zones with stockwork-impregnated mineralization are localized in the exo- and endocontacts of the porphyry tonalite bodies within the quartz-sericite (usually with anhydrite) metasomatites. Ore-bearing metasomatites are the latest formations- they are superimposed on the quartz-feldsparbiotite metasomatites and propylites.

In the Kadzharan deposit the commercial mineralization is related to the contact zone of the early monzonite-syenite (phaneritic intrusion outcropping over the area of 2000 sq. $\mathrm{km})$ with younger porphyry-like granodiorites. The mineralized blocks are saturated with intra-ore (granodioriteporphyry) and pre-ore (dioritic porphyry, syenite-porphyry) dyke-shaped bodies. According to reference [7], the absolute age of the phaneritic intrusion is 31-41 m.y, porphyry granitoids- 21-25 m.y., and dyke porphyry complex- 20-23 m.y. Within the deposit's ore-bearing stockwork there have been identified pre-ore amphibole-biotite, feldspar-quartz molybdenum- and copper-containing (with molybdenum) metasomatites. In the Kadzharan deposit, the general mineralization of the solution whose influence led to the formation of quartz-feldspar zones with molybdenum mineralization reached $50-80 \mathrm{~g} / \mathrm{l}$; the hydrothermal process itself proceeded under the temperature $420-279^{\circ} \mathrm{C}$ and pressure $80 \mathrm{Mpa}$. The later alteration of rocks - quartzsericite-chlorite with chalcopyrite, pyrite and molybdenum was associated with the action of highly-mineralized solutions $(600 \mathrm{~g} / \mathrm{l})$ on the ore-bearing medium, and the crystallization of ore-forming minerals took place within the temperature interval of $280-190^{\circ} \mathrm{C}$ and under the pressure of 70 Mpa [8].

The precipitation of ore-forming sulphides in the Tekhut deposit occurred also out of highly mineralized brines (up to $800 \mathrm{~g} / \mathrm{l})$ within temperature range of $400-220^{\circ} \mathrm{C}$ and pressure ca. $100 \mathrm{Mpa}$ [9]. Here, the phyllizites are superimposed on quartz-albite-orthoclase-biotite metasomatites and propylites. As is known, the reaction of K-feldspar-sericite-quartz is usually realized in acidic-slightly acidic solutions. For this reason, the solutions forming copper mineralization must have been most likely, slightly acidic into which, according to generally accepted opinion $[8,10,11], \mathrm{Mo}, \mathrm{Al}$ and $\mathrm{Si}$ were transported by hydrocomplexes, and $\mathrm{Cu}-$ by chloride complexes.

It should be noted, that the leading components of the deposits, $\mathrm{Mo}$ and $\mathrm{Cu}$, behave differently in the magmatic process [12]. Being high-valent and possessing high energy of Mo-O bonding, molybdenum is concentrated in the residual solution, and also is capable of isolation, together with $\mathrm{Si}$ and $\mathrm{Al}$, in magmatic fluids. Molibdenum's noncogerentence and its inability to be concentrated in rockforming minerals was also noted in reference [13]. At the same time, copper, possessing comparable energy of breaking chemical bonds with iron oxide, $\mathrm{Mg}$ and $\mathrm{Ca}$, participates in the composition of $\mathrm{Mg}$-Fe silicates, and in case of sufficien amount of sulphur can be separated as sulphides $[8,14,15]$. The phanerite complexes, which by the moment of functioning porphyry systems had been completely recrystallized, played an important role in supplying fluids with ore components. In our opinion, the influence of pellicular solutions, saturated with volatiles, on the rock-forming minerals led to the formation of autometasomatic high-temperature propylites (especially well-expressed along fault zones). The latter are represented in the Kadzharan deposit by amphibole-biotite-quartz alterations with chlorite, newly-born feldspar, dessiminated sulphide mineralization (the temperature of the process 450 $\left.300^{\circ} \mathrm{C}\right)$.

The next stage, preceding the functioning of fluidalmagmatic porphyry systems, was the invasion of gassaturated "porphyry" magmas into the phaneritic frame. Their crystallization and emission of volatiles led to the formation of explosive breccia frequently containing turmaline, quartz and sulphides. Then follows the stage of volumetrical crystallization of porphyry bodies and formation of contractional fissures into which the fluid is "engulfed" entering from the deep zones of intrusions. It is proposed that the functioning of fluidal system was preceded by following events: (1) post-solidus cooling of porphyry intrusions (800$450^{\circ}$ ) accompanied by the entering of super-critical fluid into contractional fissures (frontal zones); (2) boiling up the fluid $\left(450-400^{\circ} \mathrm{C}\right.$ and $\left.70-80 \mathrm{Mpa}\right)$ and its division into a highlymineralized brine and a gas-water mixture. At the level of the brine concentration (or the zones of lixiviation of the fluid as a result of separation of gas components) the quartz-feldspar metasomatic were formed; in the adjacent areas there were formed the zones of medium-temperature propylites as a result of the interaction of the mixture of acidic gases and previously-generated pellicular solutions from the zone of medium-temperature propylites. According to data of thermobarogeochemical investigations [8,9] propyllite and feldspar zones were formed almost synchronously within the temperature range of $450-300^{\circ} \mathrm{C}$. The stable functioning of the hydrosystems of the other types depended, in our opinion, on the thermogradiental field $\left(450-300^{\circ} \mathrm{C}\right)$ creating at the 
expence of latent heat of crystallization of magmatic bodies, and exothermal reactions of hydrotation. Taking into consideration high salinity of copper-containing solutions, the displacement of ore-forming elements in the thermogradiental fields was realized by the diffusional manner. The near-ore solution here acts as a conductor and not as a transporting agent of ore components.

\subsection{Volcanogenic Deposits}

In the central part of the Mediterranean-Himalayan Alpine mountain-fold belt fragments of paleobasin arc and adjacent backarc and intra-arc are preserved [3, 16, 17].

Here, at the active margin of the Eurasian continent, thermoanomalies arose $[18,19,20]$, the layout of which was selective, coinciding with the transformation zones. In such areas, under convergent interaction of microplates, intense volcanism and associated hydrothermal activity developed. During the convergence of microplates, first in Jurassic time, copper and barite-polymetallic volcanic deposits (Alaverdi, Shamlug, Kafan, Akhtala) and then in Early Cretaceous Tekhut type copper porphyry ores appeared on the territory of present-day Armenia. Copper, gold, barite-polymetallic epigenetic deposits (Bolnisi type) were formed in backarc volcanic depressions activated in the early stage of collision (Late Cretaceous) in southeastern Georgia, and in the west, in the eastern Pontides, as well as in Late Cretaceous, volcanogenic-sedimentary ores of copper and zinc were accumulated within the intra-arc basins (Chaely type, Turkey). Also large-scale epigenetic ores of Murgul and other deposits were formed there.

It is known that in the eastern Pontides, which developed in Alpine period as a paleoisland arc type, magmatic activity resulted in formation of significant accumulations of nonferrous metal volcanogenic and plutonigenic ores. Among them Ashikoy, Lakhanos, Kutlular, Chaely, Murgul and Guzelyala ( $\mathrm{Cu}, \mathrm{Mo})$ are considered as the economic importance deposits. It should be also noted that the Eastern Pontides are the only part of the Pontic-south Caucasian paleoisland arc, where hydrothermal-sedimentary deposits of non-ferrous metals are identified, examples of which are the Chaely (Madenkoy) and Ashikoy deposits. The Chaely deposit, also called the "pearl" of Pontides, contains a significant reserve of non-ferrous metals (15.9 m.t. of ore with the average metal content: $\mathrm{Cu}-4.4 \%, \mathrm{Zn}-6.1 \%$, Au- $0.8 \%$, $\mathrm{Ag}-44 \mathrm{~g} / \mathrm{t})$.

The Cretaceous volcanic-tectonic depression of the Bolnisi ore region, the initial stage of which development is associated with the end of convergence in the backarc residual basin, and the final formation - with the beginning of collision of lithospheric sout Caucasian and Iranian microplates, is filled with Albian-Campanian volcanoterrigenous sediments. The orebearing elements represent the synvolcanic dome-like forms, which developed at the "squeezing" sites of rhyodacitic extrusions. Extrusive (Madneuli) and lava (Darbazi, Mushevani) domes, and medium-scale collapse calderas (David-Gareji) are typical for the distribution fields of acidic and medium-acidic effusives on the slopes of large volcanic structures. It should be noted that in the Bolnisi district, industrial-scale volcanic deposits are located in the upper parts of the effusive -sedimentary rock blocks of Turonian-Santonian age, where the latter are complicated by extrusive and lava domes.

According to the reference [19] the authors hold information on isotopic composition of strontium and the concentrations of rubidium and strontium in rocks that form areas containing volcanic deposits. So, the basalts $\left({ }^{87} \mathrm{Sr} /{ }^{86} \mathrm{Sr}=\right.$ 0.704910) of the Bolnisi district may be the products of undeppletted mantle differentiation, and the magmatic source of the rhyolites $\left({ }^{87} \mathrm{Sr} /{ }^{86} \mathrm{Sr}=0.710269\right)$ of the Madneuli deposit should be located in the lower part of the upper crust. The similar characteristics of rhyolites $\left({ }^{87} \mathrm{Sr} /{ }^{86} \mathrm{Sr}=0.707739\right)$ of the Murgul deposit(Turkey) indicate their subcrustal source. The crustal origin of rhyollites and ignimbrites is evidenced by the established ratios of Europium (o.65-0.68 and 0.529.58 , respectively)in these rocks, as well as the enrichment of the rocks with light rare earth elements (LREE) and lithophilic elements with high ion radii - potassium, rubidium, barium and strontium [21].

As an example is given the Alaverdi ore region of Armenia. The Alaverdi ore region, which includes a fragment of paleoisland arc - the extreme south-western part of the Somkhit-Karabakh tectonic zone, is built in the central part, mainly by Bajocian-Bathonian and Late Cretaceous volcanic complexes. The volcanic structure of Alaverdi was formed as a result of at least three strong phases of volcanic activity. In the beginning (early Cretaceous) fissure-type volcanoes were functioning and andesibasalt and basalt composition lavas were erupting. In our view, the latter represented presubduction formations formed during the divergence of the south Caucasian and north Iranian lithospheric microplates.

Volcanic deposits are collected in geological complexes, which originated in the process of interaction of oceanic and continental plates. Usually this is the active margin of the continent where the oceanic crust undergoes subduction. The active margins were being broken at a certain stage of geological development, so they are perceived as a "grouping" of microplates.

Fluid fermentation occurred during the formation of hydrothermal-sedimentary deposits, apparently before rising to the seabed; this created favorable conditions for the operation of oreforming systems. The most conductive conditions for stable accumulation of hydrothermalsedimentary ores were created at the bottom of the sea basins, which were at a depth of 2-3 km [22]. Shallower depths of the sea basin, taking into account the physic-chemical properties of the orebearing minerals, are not "prohibited" for the above process; but the unstable environment of the sea shelf and transition zones does not facilitate the stable process of ore accumulation.

The functioning of hydrosystems in volcanic ccomplexes, in our view, was preceded by the following events: in the local depressions of the sea basins (back arc and intra-arc) terrigenous-volcanic sediments were accumulating; Then andesite-dacite-rhyollitic complexes accumulated as a result 
of volcanic activity; At the end of volcanism, andesibasalts and small volumes of sodium rhyollites erupted. As a result of decrease in volcanic activity, which was manifested in the leaching and formation of tuffites, the intrusives intruded and crystallized at a depth of about $2 \mathrm{~km}$. Note that hydrothermal deposits "at the expense of black smokers", according to modern data, were formed after the formation of andesitedacite-rhyollitic complexes (geological observations at the "Kuroko" type deposit show that ore deposits are located over the arches of rhyodacites). The zoning of hydrothermalsedimentary deposits is explained by the redistribution of the components of so called "hills" and diffusing them from the lower levels to the upper levels through fluids.

As an example we can cite the ore structure on the Explorer ridge in the Pacific Ocean [23, 24]. Hightemperature sulfides above are followed by relatively lowtemperature Fe-Mn sulfides, barite and silica. According to Grichuk [25], the anhydrite-pyrite structure (proposed thermodynamic model) will be replaced by late silica-sulfide. The formation of anhydrite in the "ore hills" is explained by the participation of seawater in the unloading zones. It is from the heated sea water that the anhydrite is released and precipitated [26].

\subsection{Gold-bearing Deposits}

Gold-bearing paleosystems are characteristic of megastructures experienced maximum tectonic stresses. They are identified in the allochthons of the Southern Slope of the Greater Caucasus and in suture zones. Gold-bearing are also collisional volcanostructures composed of terrigenousvolcanogenous flyschoids complicated by subalkaline and alkaline intrusions.

In the Zod ore field located on the obducted ophiolites of the Lesser Caucasian suture [27] the outcropping rocks are represented by pre-Cambrian crystalline schists and rhythmically-bedded volcano-sedimentary sequences of Early Senonian. The enclosing serpentinized ultrabasites and gabbroids are intensively broken up and cut by dykes of granodiorite-porphyry. Mineralized vein zones are characterized by mineralization pertaining to gold-tellurium geochemical type. The zones are marked by quartzcarbonate-talc metasomatites. Dispersional gold is concentrated in pyrites; larger native gold fractions are associated with sulphides and tellurides.

The Megradzor deposits is located at the marginal part of Daralagez block. Here, the metamorphic schists of preCambrian are overlain by Cretaceous carbonate flysch-type sediments which, in turn, pass into Eocene volcanosedimentary flyschoid rocks. The latter contain numerous syenite, monzonite, nepheline syenite, lamprophyre bodies, some of which being gold-bearing. Gold-bearing are narrow $(1.502 \mathrm{~m})$ zones of argillizites. Very typical of the deposit are ore columns characterized by high gold content (up to 500 $\mathrm{g} / \mathrm{t}$ ). Both free microscopic gold and gold in pyrite has been identified. The quartz veins contain, apart from native gold, also chalcopyrite, sphalerite, galena, white ores (tennantite) and tellurides of gold and silver (calaverite, petzite).
In the Southern Slope of the Greater Caucasus (in the north of the Transcaucasian plate) gold manifestations are related to different geotectonic situations. The most northern manifestations attributed to the quartz-arsenic type are concentrated within the areas of Neogene tectono-magmatic activization of Early Jurassic flyschoid sediments deposited in the axial zones of marginal paleobasins [28]. The sediments, as a rule, are carboniferous and low-carbonate. The mineralized zones, 5-7 $\mathrm{m}$ thick and with average gold content up to $7 \mathrm{~g} / \mathrm{t}$ (Zopkhito deposit), are represented by thin quartz-antimony veins and enclosing silicificated carboniferous shales with gold-bearing pyrite and arsenopyrite; the zones are very extensive both along the strike (hundreds of meters) and the dip (over $200 \mathrm{~m}$ ). Some of them are also tungsten-bearing. The enclosing rocks are enriched with cobalt, lithium, vanadium, arsenic, zinc; some of diagenetic pyrites are gold-bearing [29].

The second, or southern, group known in Svaneti unites gold manifestations proper that are closely related to the Middle Jurassic magmatic activization of flyschoid formations of Lower Jurassic and Paleozoic age accumulating on the continental slope.

The Paleozoic sediments have experienced greenstone alteration and are underlain by granodyorite-gneisses and amphibolite schists. The gold-bearing zones have been found in Liassic silicificated shales, Devonian metamorphites and Middle Jurassic quartz diorites cutting the older rocks. The gold-quartz manifestations are distinguished by low content of sulphides. Some of gold-bearing zones, such as those in quartz diorites, are characterized by increased content of bismuth and tellurium, and at some distance from them there are thin quartz-sheelite veins. In the Zod deposit, where gold is generally associated with pyrite, arsenopyrite and tellurides and sometimes forms with independent association realgar and cinnabar, the basite-ultrabasite complex underwent uneven greenstone alteration, and at some distance from the veins - amphibolization and quartz-albite-epidote alteration. The geological position of the Zod deposit has some resemblance to that of some ancient deposits in greenstone belts, such as Kerkland Lake and Hollinger in Canada and Noskvill in California [30].

Several possible ways of gold migration resulting in its accumulation in metasomatic sequences have been proposed by different authors. Some researchers [31] assume that solutions responsible for gold mineralization in terrigenous sediments have been formed in PT-conditions coresponding to greenschists; the others [32-34] assign the role of physicalchemical barriers to carboniferous shales.

An example of gold-bearing deposits in the ancient greenstone belts (in Abititi belt, Kerr-Edison) [30] indicated that the mineralization is distributed within the comatites with signs of liquation processes near syenite stocks. Roedder [35] assumes that the mantle material beneath the crust experienced separation into sialic alkaline-alumosilicate and mafic solutions. The latter, in the near-surface conditions, underwent liquation with separation of gold-sulphide component. This mechanism seems to be responsible for the 
initial stage of gold migration from the undercrust depths.

The next stage of gold migration is related to disintegration of ultrabasites and basites with sulphide liquates and transfer of gold, in the form of metal sol, into the flyschoid sediments. At this stage, gold is caught by organisms and sorbed by clay minerals, as is assumed by many authors [31]. Gold catching in the zones of flyschformation is a necessary, but insufficient, condition for the formation of gold deposits proper. In carboniferous terrigenous sequences, the ore-formation is preceded by some processes (metamorphism, magma-formation) that favour the generation and separation of gold-bearing "mobilizates" (fluidal and fluidal-magmatic substances).

The transformation of rocks with primary anomalies of gold in greenschist and amphibolite facies was condusive to "cleaning" of sediments from heavy metals. The further course of events may be pictured as one of the two possible ways. In the first variant, the gold mobilisate formed in amphibolite-grade conditions, was transported as a result of tectonic processes into the upper, greenschist zone where its separation into silicate and gas phases took place. Quartz veins have formed on the background of quartz-feldspar metasomatites within the inner zones of two-phase systems, whereas the outer zones have been places of impregnated sulphide mineralization (the metamorphogenic-hydrothermal model). In the second variant, under the conditions of high fluidal pressure, the fluidal-magmatic transformation of rocks and their partial melting took place. Movement of magmas toward zones of lower pressure was condusive to separation of fluid-gas components.

\subsection{Skarn Iron-ore Deposits}

Skarn magnetite deposits are concentrated in paleo-island arc structures and collisional volcanic edifies (Figure 1). In the Lesser Caucasus their typical representative is the Dashkesan deposit [36]. It is seated on the synclinal fold made up of Middle-Upper Jurassic volcano-sedimentary rocks. The Middle Jurassic formations are represented by rhyodacite flows and tuffites; the Upper Jurassic - by argillites, sandstones, marls and limestones. These rocks are intruded by a Neocomian polyphase massif consisting of gabbro, quartz diorite and tonalite. Magnetic bodies are distributed in the skarn-altered Upper Jurassic carbonate rocks - in garnet-pyroxene and dashkesanite skarns. In the north-west site of the deposit the ore bodies can be traced along the strike at a distance of $1.7 \mathrm{~km}$ and along the dip - of $1.9 \mathrm{~km}$; in the south-east - at a distance of $2.5 \mathrm{~km}$ and $1.3 \mathrm{~km}$, respectively. The magnetite ores contain sulphides of iron, nickel, cobalt, molybdenum, zink, lead and copper. Near the NW site, at the contact of a diabase dyke with Bajocian sedimentary rocks there is impregnated ore consisting of cobaltite, glaucodot, arsenopyrite. According to reference [36] (1974), the formation of pyroxene-garnet skarns at the expence of silicate rocks proceeded within the temperature range of $500-600^{\circ} \mathrm{C}$, and epidote-garnet skarns- at the range of $500-400^{\circ} \mathrm{C}$. The temperature interval of post-skarn mineralization was $420-200^{\circ} \mathrm{C}$.
The deposit was, most likely, formed at the depths of 1.5$3.5 \mathrm{~km}$ in the course of evolution of skarning fluids, in the temperature range of $740-420^{\circ} \mathrm{C}$. Other researchers [37] also agree that magnetite mineralization accompanies the skarn formation, and sometimes is superimposed on skarns that leads to the hydrolysis of skarn minerals. The following types of ores can be identified here: garnet-magnentite, garnetamphibole-magnetite, epidote-amphibole-mag-netite and epidote-chlorite-magnetite. Judging by inclusions in minerals, the ore-forming fluid had the chloride-calcium-sodium composition, the concentration of $\mathrm{NaCl}$ at the temperature of $600^{\circ} \mathrm{C}$ being $44 \%$, and at the temperature of $400^{\circ} \mathrm{C}$ - up to $26 \%$. Among the inclusions of the pre-ore stages previal gas phases, their proportion decreasing in minerals formed during the period of precipitation of the bulk of ores.

It is generally accepted that magnetite precipitated from acidic fluids on the oxidizing barrier (garnet skarns), the oxidizing-reducing medium corresponding to the conditions of the hematite-magnetite buffer [37, 38$]$. The possibility of transportation of Fe within chloride complexes [39] and its extraction from the near-ore space [37] is assumed.

Similar to the Dashkesan are the deposits Empire in Canada, Larana in the Philippines, Sinijama in Japan [39] and numerous deposits in the Pontides. The skarn-forming processes within these deposits have involved basaltoids, andesites, sandstones, marls and limestones; all of them are characterized by high content of cobalt and nickel. Magnetitebearing skarns with garnet of grossular-andradite series and with pyroxene of diopside-hedenbergite series are attributed to the oxi-dized type formed at the expence of hematite-bearing rocks [39]. It is not excluded the involvement of exogenic chloride waters - highly concentrated brines - in skarn-forming endogenic systems. The process of scapolitization is often considered to be an event accompanying the extraction of iron from gabbroids [37].

\subsection{Manganese Deposits}

The metallogenic picture of the region would have been incomplete had not we mentioned the epoch of manganeseformation coinciding with the onset of the post-collisional stage - the accumulation of the Oligocene Maikop series. This period also coincides with the formation of deep-marine hollows - the Black and Caspian seas. The major Chiatura manga-nese deposit is related to the Oligocene spongiolite sandstones and sandy-clayey sediments. The manganesecontaining horizon, corresponding to the lowermost strata of Oligocene, rests unconformably on Upper Cretaceous limestones. It is represented by alternation of ore-bearing beds and opoka-type sandstones and clays. The average thickness of the productive horizon is $4.5 \mathrm{~m}$; the thickness of ore-beds is $0.01-0.5 \mathrm{~m}$, ore-devoid beds - up to $1 \mathrm{~m}$. The productive horizon is overlain by clays and spongiolite sandstones, up to $30 \mathrm{~m}$ thick. The bulk of ores is concentrated in the lower part of the productive horizon while its upper part is poor in ore. The two parts are separated by a ferruginous layer which in the exposed portions is composed of iron hydroxides, and in the buried 
portions - of glaukonite and chlorite. Among the rocks of the productive horizon are tuffs, tuffites, layers of opoka and spongiolite. The distribution of the types expresses the facial conditions of the Oligocene time: oxidized ores (pyrolisite and polypermanganate) are developed in near-shore sediments, manganite (brown manganese ore) - in deeper portions of the basin, and finally appear carbonate manganese ores (manganese nodules, oolites, cement in sandstones). Apart from lateral, vertical zonality is also observed within the productive horizon, namely its upper part contains carbonate ores, whereas its lower part is enriched with primary oxidized manganese ores. Carbonate ores outcropping at the day-surface show the well-developed zone of oxidation.

Primarily oxidized ores are composed of oolites of pyrolisite, psilomelane, manganite whose cement is siliceous material with particles of quartz, feldspar, sponge spicula and plant detritus. The carbonate ores contain mangano-calcite, calcium rhodochrosite, calcite, opal, a small amount of barite, gypsum and sulphides of iron.

Some researchers [40] attribute the Chiatura deposit to sedimentary deposits, others [41] - to exhalationalsedimentary formations. The proponents of the exhalationalsedimentary origin assume that ores were concentrated in the Oligocene sub-oceanic basin (Paratethys), within its riffogenic depressions. In their opinion, the volcanic centres were distributed to the south and west-southwest of the orebearing basin. According to the proponents of the sedimentary genesis, the ore-accumulation took place in a wide gulf. From the mainland the ore-containing sediments were bordered by beach sands, and from the open sea - by more deep-marine sediments (clays, marls). The source of manganese may have been the pre-Mesozoic metamorphites, mainly metabasites, as was assumed in case of the Nikopol deposit in the Ukraine. In the Betekhtin's opinion [40], pyrolusite-psilomelane ores were deposited in the zone enriched with oxygen from the colloidal solutions.

The analysis of facial-petrographical conditions of the formation of the Maikop series gave Stolyarov [42] a ground to state that the Caucasus and Transcaucasia in the Oligocene represented an archipelago tightly conjugated with deep-sea troughs. The manganese ores are concentrated in the periphery of the deep-marine paleo-hollows, whereas the iron ores - in the near-shore zones. The manganese ores are practically devoid of iron. Stoljarov, at the example of the Northern Aral region came to the conclusion that iron was concentrated in the near-shore zone where it was transported from the areas of erosion of greenstone rocks in the Mugodjari Mountains. Since the separation of $\mathrm{Fe}$ and $\mathrm{Mn}$ derived from a single source area seems very unlikely, their separated positions may evidence another source of manganese - intrabasinal.

\section{Discussion}

Porphyry deposits represent an example of maximum closeness and sometimes even juxtaposition, of discharge zones of fluidal systems and their energy sources. Porphyry intrusions, during the period of their fluidal systems' functioning, were located at the depths of 1-3 km from the paleosurface, and their crystallization proceeded within temperature range of $1230-800^{\circ} \mathrm{C}[43,11]$. The zones of the formation of phaneritic intrusions were deeper levels (5-10 $\mathrm{km}$ ) of the earth's crust. The sources of both judged by their petrochemical composition, were located in lower crust and undercrust zones of the lithosphere [44].

Many authors [43, 11, 24, 45] arrive at a conclusion that both magmatic and exogenic sources participate in oreforming process (isotopic-geochemical data). The model of two fluids proposed in the 70-ies by Taylor [47] still remains popular.

In our ideal-logical model we give preference to the magmatic source. The process of mineral-formation is regarded as one proceeding in a single porous-water space around small intrusives; within this space ore components moved diffusively and precipitated in the form of zols at reaching the critical isothems. Within the latter, took place the disintegration of metal-locomplexes at the expence of temperature increase and corresponding enhancing of association of acidic components ( $\mathrm{H} 2 \mathrm{~S}, \mathrm{HCl}$ and others). At the beginning of mineral-formation process at the deposits of copper specialization, the precipitation of angidrite, along with quartz, took place $\left(380-340^{\circ} \mathrm{C}\right.$, temperature of homogenesis of gas-fluid inclusions of the quartz-angi-drite paragenesis). The steady mineral formation continued within the temperature range of $300-200^{\circ} \mathrm{C}$. With this, in every concrete site, there took place the increase of solution acidity related to the retreat of critical isotherms that is evidenced by superimposition of quartz-sericite paragenesis on feldspars. The bulk of copper was precipitated under above temperatures and pressures up to $50 \mathrm{Mpa}$. It should be also noted that the monotone accumulation in unstable tectonic settings was replaced by infiltration of ore-bearing solutions along fault zones, and by precipitation of ore matter. Outside the porphyry and even the phanerite bodies, quartzmolybdenite and quartz-pyrite-chalcopyrite veins are developed within the ore fields.

The precipitation of ore matter is satisfactorily explained by the increase of water polymorphism in anomalous temperature points [20] changing acidic-basic properties of the solvent. The anomalous temperature zones can be areas of accumulation of acidic components (in the first place $\mathrm{H}_{2} \mathrm{~S}$ ) whose interaction with metal-carriers will inevitably lead to the precipitation of sulphides, the alkalization of solutions due to the loss of $\mathrm{HCl}$, and reaction of hydration (quartzsericite alteration).

At volcanic deposits ore-forming processes take place in an open system [48]. It develops as follows: 1. Fluid formation areas; 2 . their movement; 3. Unloading areas in certain geological structures (physical and geochemical barriers), where ore material accumulates.

Here is a model of ore-forming system development, first of all the stage, when the ore separation and accumulation took place. The model emphasizes the necessary and sufficient signs for the ore-forming processes, using 
thermobaric and isotopic data. We also note that the genetic model is perceived by us as an abstraction, which takes into account not the external properties of ores and ore bodies, but the standardization of the processes occurring in the system.

The salinity of hydrothermal solutions containing ore elements is close to that of seawater; at the same time hydrothermal solutions are enriched in $\mathrm{Fe}, \mathrm{Ag}, \mathrm{Pb}, \mathrm{Zn}$ and $\mathrm{Cu}$ compared to seawater [49]. Initially, the redistribution and separation of ore components is related to the crystallization conditions of magmatic rocks, for example, Prokovtsev [50] noted the separation of ore aggregates in mid-ocean basalts. The presence of "droplets" of sulfides has also been established in clinopiroxenes and feldspaths (anorthite) of mid-ocean ridge rift basalts [51]. Nickel pyrhotite, sphalerite, chalcopyrite, albite, K-feldspath, and silver are defined in these ore liquids.

Large-scale ore-forming process in the world ocean takes place by the following sequential processes: 1. magma crystallization; 2 . Interaction of surface waters and volcanites; 3. In case of existence of physical-chemical barrier operation in unloading areas of hydrotherms in the seabed or near the surface.

Non-ferrous metal volcanic deposits are characterized by the following features:

1. Hydrothermal-sedimentary and veinlet-impragnated deposits are associated with volcanic depressions; the first in most is cases related to its axial parts, the latter to the lateral parts and is controlled by the arches of the extrusives.

2. The component composition of ores depends on the petrochemical properties of ore-bearing volcanites and their comagmatites. Barite-polymetallic mineralization is associated with rhyodacites, and copper and zinc mineralization - with andesite-basalts and rhyolites.

3. Mineralization of industrial importance depends on the volume of ore-bearing depressions (the volume of volcanites in them) [18].

4. Fluid migration paths within ores are reflected in hydrothermally altered rocks, by development of hydromicas, montmorilonites, and chlorites in downstream flows, and in the upper parts of the intrusives of large-scale propyllites and on the sides of depressions. Ascending streams of hydrotherms near shallow and relatively shallow depths near the surface of barite-sulfide deposits are marked by explosive breccias, which as a result of hydrothermal alteration, are transformed into secondary quartzites and quartzadular-sericitic metasomatites.

5. Barite-sulfide ores usually are located in secondary quartzites (Madneuli deposit). Here in vein zones the barite-sulfide ores are changed with sphalerite-galenachalcopyrite association to depth. Interestingly, the veinlet-impragnated ore bodies are bordered on the top by effusives and bodies, and at depth by the finegrained pyritic (chalcopyrite) zones of gypsum and jasper quartzites [18]. Chalcopyrite-pyrite and sphalerite ores in the upper parts contain schlieren, which are filled with quartz, pyrite, chalcopyrite, bornite, coveline. On the top of copper mineralization zones, except gypsumanhydrite lences, quartz-hematite accumulation has also detected. The above-mentioned "mineral picture" of copper-zinc veinlet-impregnated ore mineralization is typical for "Kuroko" type hydrothermal-sedimentary deposits. [52].

6. Fluids forming volcanogenic deposits were characterized by low acidity, low salinity, and sodium chloride composition [53,37].

7. Data from hydrogen and oxygen isotopes in quartz, barite and calcite of barite-polymetallic ores of volcanogenic deposits indicate the high role of meteoric waters in the ore-forming process. Magmatogenic water is of greater importance in copper ores than meteoric water $[53,55,11]$. The data on oxygen isotopes obtained by us (USGS) do not contradict these data.

Unfortunately, it was not possible to study the gaseousliquid inclusions on the Chaely deposit (Turkey). We therefore used data from deposits that, we believe, belong to the Kuroko type deposit [56]. In particular, these are the hydrothermal-sedimentary deposits of the Keramdek islands arc. As a result of thermobarogeochemical studies of gasliquid inclusions, the salinity of the hydrothermal solution ranges from 175 to 3.9 wt $\%$ eq. $\mathrm{NaCl}$. Homogenization temperature ranges from $475-322^{\circ} \mathrm{C}$. Two phase inclusions predominate, rarely monophasic. The average salinity is approaching to the salinity of the sea water (3.9 wt \% eq. $\mathrm{NaCl})$. The solution fermentation did not occur. The coexistence of gas and solution enriched inclusions under the same temperatures is not observed. Also methane was determined by gas chromatography: $\mathrm{H}_{2}(99,8-99,98$ mol,\%); $\mathrm{CO}_{2}(0.3-0.17) ; \mathrm{N}_{2}(0.004-0.23)$ and $\mathrm{CH}_{4}(0.002-0.026)$. The authors of this paper suggest that methane is of abiogenic origin. Examples show that hydrothermal-sedimentary and epigenetic type deposits confirm the notion [54] that ore accumulation in volcanogenic deposits occurred under the same PT conditions. Madneuli type deposits were formed after the formation of rhyodacite bodies (barite and baritepolymetallic bodies), and later as a result of the intrusion of porphyry granodiorites (impregnated stockwork mineralization).

There is a clear regular connection between gold-bearing paleosystems and blocks of the earth's crust which show intensive lateral metamorphism and traces of mantle diapirism (in the form of various magmatic substances). In some cases, as in the Greater Caucasus, the most suitable process might have been, in our opinion, one of successive concentration of gold. It should be noted, however, that the interaction of mantle diapirs here was realized within the limits of conservative transform paleostructures. The granitoid magma, that might have been formed at the expence of metaflyschoid and metavolcanic se-quences [57], disaggregated liquates during its slow raising which were preserved in the form of schlier pegmatites. In case of rapid raising of magma to the higher level ("shock" decompression) related to fast volumetrical expansion, its separation into 
silicate and fluid-gas components took place. The latter, in turn, was the source of fluidal flows whose components precipitated, under abrupt dropping in pressure, in the contractional fissures in hardened parts of magmatic bodies or in the enclosing rocks.

It should be also noted that the composition of the primary anomalies of gold in different parts of the southern slope of the Greater Caucasus could have been different. In the north part of the southern slope where sediments of deep hollows of the paleomarginal sea are exposed, the primary goldcontent may be influened by volcanic processes and related hydrothermal activization. Here gold, at the stage of its initial concentration, was distributed in sulphides syngenetic to the enclosing sediments. The Zopkhito and other deposits reveal positive correlation between gold, on the one hand, and nickel, cobalt and arsenic, on the other. As for the Svaneti gold manifestations, they are concentrated in metaflyschoids accumulated on the continental slope, and in quartz-diorite bodies that intruded these metaflyschoids; by their type these manifestations are attributed to gold-quartz type. In the formation of primarily - gold-containing surroundings the prevailing role belonged to exogenic processes. In case of gold manifestations in volcano-plutonic belts or within the microplates experienced late tectono-magmatic activization, the association of magmatic formations (subalkaline and alkaline syenites, lamporphyry) syngenetic to gold indicates the possibility of the genesis of their fluidal-magmatic systems at under-crustal depths.

The process of ore-formation was proceeding mainly in oxidizing conditions (iron-ore deposits are usually accompanied by oxidized-iron associations - garnet-angidrite series and epidote).

According to Stolyarov [42] deep-water parts of Paratethys as well as the Black sea underwent in the Oligocene time sulphuretted hydrogen contamination. The ability of manganese for accumulation in dissolved state in the sulphuretted hydrogen waters was determined [58]. The main impulse of manganese-formation coincided in time with the uplift of sea bottom and ingression of the sea that is evidenced by occurrence of ores on the ancient formations including crystalline schists of the basement. Deep waters (with sulphuretted hydrogen and manganese) entered the shelf zones characterized by high oxidized hydrogeochemical barrier where manganese hydrooxides were deposited.

\section{Conclusions}

As an example of the Eurasian active continental paleomargin (Pontian-Transcaucasian microplate) demonstrates, the onset of the Alpine cycle was heralded by the maximum approaching of the non-depletive mantle plumes to the day-surface in divergent zones, and by intrusion of mantle differentiates into the marginal parts of the microplate. These processes induced the functioning of hydrothermal systems as a result of which were formed copper- and pyrite-polymetallic volcanogenic-sedimentary ores. At the convergent stage (microplates' approach), there appeared andesitic volcanism within island arcs systems resulting in the emergence of ore-magmatic systems and formation of volcanogenic-sedimentary and epigenetic deposits of non-ferrous metals as well as skarn-iron and copper-porphyry ores. During this time, the sediments of the marginal sea were subjected to tectono-metamorphic transformation and were complicated by gabbro-tonalite magmatites. In our opinion, the Middle Jurassic was the time of the final formation of metamorphic belts the root parts of which underwent fluidal-magmatic replacement within amphibolite facies thermo-dynamic conditions. Formed in this way fluidal-magmatic systems were mainly gold-bearing.

The collisional stage was a time of microplates'destruction and heterogenesis. Within the microplates there was, along with andesitic volcanism, a paroxysm of shoshonitic and, locally, alkaline volcano-plutonic activity. In the residual back-arc and superimposed volcanostructures appeared fauvorable conditions for functioning barite-, copper- and gold-bearing hydrosystems.

Very important, in respect of metallogeny, also was the post-collisional stage, especially its initial phase when large copper-molybdenum, economical gold-bearing, antimony, mercury and arsenic deposits were generated. The Oligocene time is, not without reason called an epoch of large-scale manganese formation in residual marine basins.

The above material allows to draw the following conclusions:

(1) Plutogenic deposits of the porphyry family form at certain stages of the evolution of a continental active paleomargin: medium-scale deposits - within island-arc systems; large copper-molybdenum-porphyry - at the junction of microplates at the beginning of the postcollisional stage. With all this, the ore-forming process is preceded by a preparatory stage which covers a few tens of million years. It starts with magma-formation in the lower crust and upper mantle which is followed by the replacement and crystallization of magmatic masses. Later, after some interval ( 10 m.y.), new tectonic stresses may re-appear and porphyry bodies intrude into crystallized phaneritic massifs. The latter occupy the apical parts of large massifs. Under the influence of the heat flow of small intrusions and relaeasing volatile components, together with mineralized porous waters, porphyry ore-magmatic systems form and function.

Within the relatively closed water-porous space specialized in this or that element depending on the enclosing rocks, ore components diffuse in complex thermo-gradiental field, reach critical temperature zones and then precipitate as a bulk of sulphides and sulphates.

(2) The processes of volcanism and ore-formation are interrelated. But for the generation and functioning of oreforming systems the following conditions should be realized: a) the presence of "specialized" geological environments; b) sufficient amount of sulphur (biogenic and endogenic); c) stable energy supply (intrusions); d) durable and stable functioning of physiscal and geochemical barriers; e) sufficient amount of solvent. All these requirements are realized at earlier stages of the evolution of rift depressions, and later - in marine hollows 
and within volcanodepressions superimposed on the deep structures which, most likely, are of transform nature. The solvent of metals for copper- and copper-zinc-bearing hydrothermal systems was sea water metamorphosed under the influence of intrusion's heat flow; and for barite- and polymetallic systems -sodium-chloride brines of primarilymarine origin containing in evaporitic sequences.

(3) Gold-bearing deposits proper reveal in certain cases clear relations to carboniferrous formations (the southern slope of the Greater Caucasus), in others - to differentiates of the mantle matter (suture zones and margins of microplates). The former were characterized by the following succession of migration and concentration of gold:

a) first, gold was accumulated in primary exogenic anomalies;

b) later, gold-bearing carboniferrous formations experienced fluidal-magmatic replacement;c) at hypabissal level, separation of gold-bearing mobilizate from the fluidalmagmatic system took place.

The earth's crustal blocks in which gold-bearing systems were functioning are characterized by intensive lateral metamorphism and the presence of products of differentiation of mantle material. In the Racha region, the influence of volcanic processes on the concentration of gold in primary anomalies was considerable enough. In Zopkhito, gold in syngenetic sulphides reveals positive correlation with nickel, cobalt, arsenic and antimony. As for the Svaneti gold manifestation, there, in our opinion, the role of exogenic processes in the formation of primary gold anomalies was prevailing. The sources of anomalies may have been ancient ultrabasite-basite complexes and the migration of gold into the fluidal sediments was realized by paleostreams whose channels developed along transversal deep-seated conservative faults. Gold being transported as metal-zols was caught by organizms and absorbed by clay minerals.

Volcano-plutonic belts may have been, as indicated by a paragenetic association of migmatites (basites, subalkaline and alkaline rocks, lamporphyre), the place of origin of goldbearing magmatic systems at undercrust depths and their later transformation in ore-magmatic systems at hypabissal and subvolcanic levels. In suture zones, gold-bearing systems may have been formed near the places of discharge as a result of interaction between fluidal flows and basite-ultrabasite complexes. The latter may have served as sources of ore matter, gold, in the first place.

(4) Skarn-ore paleosystems developed in such blocks of the earth's crust where, prior to the displacement of intrusions (at the end of the subduction and collisional stages) were created favourable conditions for concentration of iron. In such places, chloride brines for a long time were in equilibrium with hematite-bearing volcano-sedimentary sequrnces. This assumption is confirmed by the presence of widespread mineral associations (scapolite, dashkesanite, Cl-enriched mica).

(5) Manganese accumulation may have taken place in shelf zones of residual marine basins under following conditions: a) the presence, according to reference [56], of intrabasinal manganese-bearing hydrosystems formed, most likely, as a result of interaction between $\mathrm{H}_{2} \mathrm{~S}$-containing sea waters and ultrabasites and volcanic exhalations;

b) possibility of hydrothermas' entering the shelf zones (in case of abrupt oscillation of sea bottom);

c) mixing of metal-bearing and oxygen-bearing waters.

Precipitated on the oxidizing barrier, suspensions of manganese oxide were accumulated in the hollows of the shelf zones from which they were transported by coastal currents. Thus, we can draw a conclusion that the formation of fluidal systems is a regular geologic process which accompanies the regular evolution of continental paleomargins.

The area of activity of fluidal paleosystems was mainly the zones of influence of conservative transform structures, within which during the period of slackening of tectonic stresses (at the beginning of divergence, at the end of subduction stage, at the end of collision) were created the necessary prerequisites for:

a) Magmatic differentiation of undercrust material (latecollisional gold-bearing systems of suture zones and continental rifts);

b) Fluidal-magmatic replacement of metal-containing meta-sedimentary rocks (gold-bearing systems in carboniferous sequences and small granitoid bodies;

c) Transformation of marine and meteoric waters under the influence of intrusions (ore-bearing systems in volcanic formations);

d) Formation of multiphase hypabyssal intrusions whose magmas were supplied, most likely, form undercrust depths (copper-molybdenum-porphyry systems);

e) Formation of hydrosystems (with heterogenous source of ore matter) in the residual deep hollows of marginal seas and their evolution in tectonic instability conditions (manganese-bearing systems).

The work has been fulfilled under the financial support of the Al. Janelidze Institute of Geology, Tbilisi State University.

\section{References}

[1] Vrielinck B (1994). Tethys - l'histoire d'un ocean disparu. Geochronique, No 52. Bureau du richerches geologiques et minieres Societe Geologique de France. P. 14-18.

[2] Monin A. S, Zonenshain L. P (1987). Hystory of the ocean Tethys. Moscow Institute of Oceanology. 155 p. (in Russian)

[3] Sosson M, Rolland Y, Muller C, Danelian T, Melkonyan R, Adamia Sh, Baba-Zade V, Kangarli T, Avagyan A, Galoyan1 G, Mosar J. (2010). Subductions, obduction and collision in the Lesser Caucasus (Armenia, Azerbaijan, Georgia), new insights. In: Sedimentary Basin Tectonics from the Black Sea and Caucasus to the Arabian Platform. Geological Society, London, Special Publications; v. 340, p. 329-352.

[4] Yilmaz A, Adamia Sh, Chabukiani A, Chkhotua T, Erdogan K, Tuzcu S, Karabiyikoglu M (2000). Structural correlation of the Southern Transcaucasus (Georgia) - Eastern Pontides (Turkey). In: Tectonics and magmatism in Turkey and the surrounding area. Geolog. Soc. London. Spec. publ. 173. P. 71-182. 
[5] Dixon C. J, Periere J (1974). Plate tectonics and mineralization in the tethyan region. Mineral. Deposita (Berlin). 9. P. 185-198.

[6] Er Murat, Ozdogan Kemal, Tüysür Necatu. (1995). Geology and mineralization of Güzelayla porphyry $\mathrm{Cu}-\mathrm{Mo}$ occurrence. Geology of the Black sea region. MTA Ankara. P. 226-231.

[7] Mkrtchyan S. S, Karamyan K. A, Arevshatyan T. A (1969). Kadjaran copper-molybdenum deposit. Erevan: ArmSSR Acad. of Sciences publ. 269 p. (in Russian).

[8] Doebrich J. L, Baba-Zade V, Kekelia S, Ramazanov V, Mamedov Z, Ismailova A, Abdulaeva Sh, Kekelia M, Kuloshvili S, Gagnidze N, Sadradze N. (2008). Geologicalgeophysical and geochemical models of ore-magmatic systems of Kedabek ore district copper-porphyry deposits. Proceedings of the Institute of Geology of Georgia, New series, 124 issue, p. 307-315.

[9] Ratman I. P, Kekelia S. A, Narozauli I. G (1985). Zoning of porphyry copper-molybdenum deposits related to dioritetonalite-plagiogranite complexes (as an example of the Tekhut deposit, Armenian SSR). All-Union Mineralogical Society Trans. Issue 3. P. 167-168. (in Russian).

[10] Wood S. A, Crearer D. A, Borzik M. P (1987). Solubility of the assemblage pyrite-pyrrotite-magnetite-sphalerite-galenagold-stibnite-bismuthinite-argenite-molybdenite in $\mathrm{H}_{2} \mathrm{O}$ $\mathrm{NaCl}-\mathrm{CO}_{2}$ solution from $200^{\circ}$ to $350^{\circ} \mathrm{C} / /$ Econ. geology. V. 82. P. $1864-1887$.

[11] Krivtsov A. I, Bogdanov Y. V, Borodaevskaia M. B et al. (1987). Copper deposits: types and formation conditions. Moscow: Nedra publ. 197 p. (in Russian).

[12] Shipulin F. K, Rekharski V. I, Razbianskaia A. A, Pashkov Yu. N, Kapsamun V. P, Zvyagintsev L. I, Lante E. K, Kanstel A. V, Avetisyan G. G, Sukhorukov Yu. T (1975). Intrusions, hydrothermal-metasomatic formations and copper-molybdenum mineralization. Moscow: Nauka publ. 231 p. (in Russian).

[13] Candella P. A, Holland N. D (1986). A mass transfer model for copper and molybdenum in magmatic hydrothermal systems: the origin of porphyry-tape ore deposits //Econ. Geol. V. 81. P. 1-19.

[14] Barnam K. U (1983). Values of volatile components. In: H. S. Yoder (ed.). The evaluation of the igneous rocks. Moscow: Mir publ. P. 425-467 (in Russian).

[15] Popov V. S (1988). Magmatic sources of ore matter in porphyry molybdenum and copper deposits. //Geology of ore deposits. N4. P. 8-47 (in Russian).

[16] V. Baba-Zade, S. Kekelia, Sh. Abdulaeva, M. Kekelia. (2015). Orebearing sulfide deposits of paleoisland arc system, their metallogenic peculiarities and conditions of geodynamic development (on the example of Alpides and Lesser Caucasus). Baku. "CBS" publish. 400p. (in Russian)

[17] Kekelia S, Kekelia M, Gagnidze N, Popkhadze N. (2017). Volcanogenic deposits of non-ferrous metals of paleo island-arc constructions and problems of ore genesis (on the example of ore districts of Georgia, Armenia, Azerbaijan and Turkey). Bulletin of the Kiev State University, \#4 (79).
[18] Kekelia S. A, Ambokadze A. H, Ratman J. P (1993). Volcanogenic deposits of non-ferrous metals of paleoislandarc systems and methods of their prognosis. Tbilisi: Metsniereba publ. 96 p. (in Russian).

[19] Kekelia S, Kekelia M, Otkhmezuri Z, Moon Ch, Ozgur N. (2004). Ore-forming systems in volcanogenic-sedimentary sequences, on the example of non-ferrous metal deposits of the Caucasus and Eastern Pontides. Bull. MTA, 129, p. $1-16$.

[20] Baba-Zade V, Kekelia S, Abdulaeva Sh, Kekelia M. (2020). Main features of The Caucasus metallogeny. Moscow, "Nedra", 187 p. (in Russian)

[21] Gugushvili V, Kekelia M, Moon Ch, Natsvlishvili M. (2002) Crustal and mantle sources of the Cretaceous volcanism and sulfide ore fprmation at Bolnisi orefield. // Bulletin of the National Academy of Sciences of Georgia. Vol. 117. P. 412 419 .

[22] Gablina I. F, Mozgova N. N, Borodaev Yu. S, Stepanova T. V, Cherkashev G. A, Iljin M. I (2000). Copper sulfide association in recent oceanic ores of the Logachev hydrothermal field (Mid, Ocenic ridge, $14^{\circ} 45^{\prime} \mathrm{N}$ ) //Geology of ore deposits. V.42. N4. P. 329-349. (in Russian).

[23] Hannigton M. D., Peter J. M., Scott S. D. (1986). Gold in sea-floor polymetallic sulfide deposits. //Econ. geol. V. 81. P.1867-1883.

[24] Elianova E. A. (1989). Formation of composition and structure of the ore at the modern and ancient VMS system. Soviet geology, 12, 17-26. [In Russian].

[25] Grichuk D. V. (1999). Model of genesis of the sulfide ore body in the submarine hydrothermal system. In: Models of volcanogenic-sedimentary ore-bearing systems. Thesis of report. St. Petersburg. P.19-21. (in Russian).

[26] Cherkashev G. A., Jirnov E. A., Stepanova T. V., Mozgova N. N. (1999). Zonality and model of formation of the oceanic sulfide deposits. In:Models of volcanogenicsedimentary of the ore-bearing systems. Thesis of report. St. Petersburg. P. 141-142 (in Russian).

[27] Kekelia S, Kekelia M, Kuloshvili S, Razmadze A, Gagnidze N, Sadradze N, Yaroshevich V, Asatiani G, Doebrich J. L, Goldfarb R. J, Marsh E. E. (2008). Gold deposits of the Greater Caucasus, Georgia Republic: their genesis and prospecting criteria. "Ore Geology Reviews", Vol. 34, issue 3, p. $369-386$

[28] Kekelia S, Kekelia M, Asatiani G, Gigiadze G, Shavishvili I. (2005). Gold potential of deposits of Georgia. Mining Journal, \#6, p. 9-11.

[29] Kekelia S, Kekelia M, Asatiani G, Gagnidze N, Popkhadze N, Kharazishvili G. (2016). Gold Potential of Georgia. Bulletin of the Georgian National Academy of Sciences, vol. 10, no. 4 , Tbilisi. p. 41-49.

[30] Nekrasov E. M (1988). Endogenous gold deposits of the world. Moscow: Nedra publ. 286 p. (in Russian).

[31] Kekelia S, Kekelia M, Gagnidze N, Popkhadze N, Mshvenieradze I, Lonbjhanidze K, Kharazishvili G. (2017). Svaneti Gold Deposits (Kirar-Abakuri Ore Knot) and Their Genesis. Bulletin of the Georgian National Academy of Sciences. Vol. 11, № 2, p. 60-68. 
[32] Kekelia S, Kekelia M, Popkhadze N, Mshvenieradze I, Gagnidze N, Asatiani G, Lonbjhanidze K. (2017). Geological Settings and Genetic Model of the Zopkhito Prospect (southern slope of the Greater Caucasus, Georgia). Bulletin of the National Academy of Sciences of Georgia. Vol. 11, №4 P. 60-65.

[33] Volkova I. B (1992). Organic petrology of metalliferous black slates-goals and objectives of study //Soviet geology. N7. P. 11-17 (in Russian).

[34] McKeag S. A, Craw D, Norris R. J (1989). Origin and deposition of a graphite schist-hosted metamorphogenic AuW deposit, Macraes, East Otago, New Zealand//Miner. deposita. V. 24. Issue 2, pp. 124-131.

[35] Roedder E. (1983). Liquation of silicate magmas. In: Evolution of the igneous rocks. Moscow: Mir publ. P. 24-66 (in Russian).

[36] Sokolov G. A, Grigoriew V. M (1974). Iron deposits. In:Ore deposits of the USSR. Moscow: Nedra Publ. P. 9-108.

[37] Sinyakov V. I (1986). General ore genesis models for endogenous deposits. Novosiirsk: Nauka publ. 243 p. (in Russian).

[38] Kalinin D. V (1969). Experimental investigations of physical-chemical conditions of the scarn processes. Novosibirsk: Nauka publ. 175 p. (in Russian).

[39] Einaudi M. T, Meinert L. D, Newberry R. D (1984). Scarn deposits. In: Genesis of ore deposits. Moscow: Mir publ. P. 401-515 (in Russian).

[40] Betechtin A. G (1946). Industrial manganese deposits of the USSR. Moscow-Leningrad. AN USSR. 135 p. (in Russian).

[41] Makharadze A. I, Chkheidze R. G (1971). Lithology of oligocene deposits Kvirila depression. KYMS. Tbilisi. P. 177-188. (in Russian).

[42] Stolyarov A. S (1993). Genesis of the phanerozoic manganese deposits //Otechestvennaya geologia. N5. P 2833 (in Russian).

[43] Titley S. R, Beane R. E (1984). Porphyry copper deposits. In: Genesis of ore deposits. V. 1. Moscow: Mir publ. P. 245-333 (in Russian).

[44] Baba-Zade V, Kekelia S, Abdulaeva Sh, Kekelia M. (2017). Ore deposits of the central part of Alpine mountain-fold belt and problems of their genesis (Greater and Lesser Caucasus, Eastern Pontides). Baku, "CBS”. 288 p. (in Russian).

[45] Zvezdov V. S, Migachov I. F, Grifonov M. M, Zairi N. M (1989). Formation environments for porphyry copper oremagmatic systems //Geology of ore deposits. N4. P. 23-37 (in Russian).
[46] Krivtsov A. I (1989). Applied metallogeny. Moscow: Nedra publ. 288 p. (in Russian).

[47] Taylor H. P (1982). Oxygen and hydrogen isotopes in hydrothermal deposits. In: Geochemistry of hydrothermal ore deposits. Moscow: Mir publ. P. 200-237 (in Russian).

[48] Korzhinski D. C. (1982). Theory of metasomatic zonality. Moscow, Nauka, 104 p. (in Russian).

[49] Mottl, M. J, Holland, H. D, Corr, R. F. (1979). Chemical exchange during hydrothermal alteration of basalts seawater. Experimental results for $\mathrm{Fe}, \mathrm{Mn}$ and sulfur apecies. Geochim et acta, 43, 869-884.

[50] Prokoptsev G. N, Prokoptsev N. G (1990). Formation of metalliferous hydrotherms at oceanic floor. USSR Acad. of Sciences Trans. Geol. ser. N4. P. 34-44. (in Russian).

[51] Akimtsev V. A, Shorapov V. N (1993). "Ore-bearing" effusives of the side at the rift valley of the Mid Atlantic Ridge //Russia Academy of Sciences Bull. 331. N 3. P. 329 331 (in Russian).

[52] Matsukama T, Khorikosi E (1973). A review of Kuroko deposits in Japan. In: Volcanism and ore formation. Moscow: Mir publ. P. 129-151. (in Russian).

[53] Franklin J. M, Lydon J. W, Sangster D. F (1984). Base metal massive sulfide deposits of volcanogenic affinities. In: Genesis of ore deposits. V. 2. Moskow: Mir publ. P. 39-252 (in Russian).

[54] Ovchinnikov L. N. (1988). Formation of ore deposits. Moscow: Nedra publ. 255 p. (in Russian).

[55] Yaroshevich V. Z. (1985). Genetic features of ore formations of the Caucasus according to the isotope studies. Abstract of Candidate thesis. - Tbilisi: Metsniereba, 52 p. [In Russian].

[56] de Ronde C. E. J, Faure K, Bray C. J, Chappell D. A, Ian C. Wright I. C. (2003). Hydrothermal fluids associated with seafloor mineralization at two southern Kermadec arc volcanoes, offshore New Zeland. Mineralium Deposita, 38, p. $217-233$.

[57] Letnikov F. A (1997). Processes of self-organization during formation of magmatic and hydrothermal deposits//Geology of ore deposits. N4. P. 307-322 (in Russian).

[58] Kholodov V. N, Nedumov R. J (1991). Geochemical criteria for hydrogen sulfide contamination of ancient water bodies. AS USSR. Geol. ser. N 12. P. 74-82 (in Russian). 